\title{
The Working Conditions and Optimization of a Large Rainwater Harvesting and Treatment System in an Area at a Risk of Erosion
}

\section{Tomasz Zubala ( $\nabla$ tomasz.zubala@up.lublin.pl)}

University of Life Sciences in Lublin: Uniwersytet Przyrodniczy w Lublinie https://orcid.org/0000-0001-8308-3515

\section{Research Article}

Keywords: rainwater, pollutant, treatment, erosion, modernisation

Posted Date: July 6th, 2021

DOI: https://doi.org/10.21203/rs.3.rs-575553/v1

License: (c) (i) This work is licensed under a Creative Commons Attribution 4.0 International License. Read Full License 


\section{Abstract}

The study evaluates the operation of rainwater harvesting and treatment systems (RHTS), receiving effluents from the wholesale market and fuel station (twenty years of observations). Changes of the basic elements of RHT systems (e.g. earthen reservoirs - sealed settler, infiltration reservoir) were characterized and the impact of climatic conditions on the system monitored. The analyses also referred to the stability and work safety of the most important equipment and water treatment efficiency. In the study period, due to the accumulation of erosive phenomena, it was necessary to optimize the system. The infiltration reservoir was considerably modified. At the same time, another reservoir of a similar type was built. The quality of water in the reservoirs were measured in 2008-2010 (before the modernisation) and in 2016-2018 (after the modernisation). Selected physical, oxygen, biogenic and salinity indicators were determined in the water. During the study the harvesting and treatment system had a positive effect on the quality of rainwater runoff the values of many contaminants were reduced (RHTS 1: suspended solids, nitrogen, iron, potassium; RHTS 2: conductivity, suspended solids, nitrogen). Design and operational errors were noticed that in the long run may contribute to deteriorating the operational efficiency and even lead to a building collapse (intense erosive phenomena). This study clearly demonstrates that building a rainwater management system is a highly site-specific issue.

\section{Introduction}

The negative effects of progressing urbanisation include deterioration of the status of water resources. This is a result of levelling and sealing the surface of land and, as a consequence, deformation of the local hydrological cycle. A larger non-permeable area means an increase in the volume of rainwater that needs to be safely collected and disposed of into receiving bodies. Municipal sewerage systems show increasing flow rate irregularity and hydraulic overloading. Building development and sealing of the grounds additionally decreases the amount of water soaking into soil, thereby reducing the possibility of natural self-purification and renewal of underground water resources (Geiger and Dreiseitl 2001; Hatt et al. 2004).

Rainwater and melt-water runoff in urbanised areas can contain considerable amounts of pollutants, and so they pose a risk to natural receiving bodies such as water and soil. Scientific literature points to a strong correlation between the method of development of the drained area and the quality of precipitation run-off. Increased migration of pollutants can be expected in the case of road infrastructure, city centres, industrial grounds, and certain types of roofing material (Liu et al. 2014; Zhang et al. 2014; Zubala 2018).

It is possible to decrease the risk of overloading the sewerage system and environmental pollution by reducing the volume of rainwater runoff and the load of pollutants it transports at the point of origin. In areas where a lot of free space is available, simple solutions, such as retention ponds or wetlands, are often the right choice. Dilution, sedimentation and biological reduction of pollutants takes place in those structures (Ivanovsky et al. 2018; ManiquizRedillas et al. 2014). Storage and pre-treatment of rainwater runoff within the existing sewerage system can be very advantageous. To this end separators, wells, settling tanks and infiltration basins are used. These facilities work on the principle of separating substances of different density due to the force of gravity (sedimentation), adsorption or coalescence (Geiger and Dreiseitl 2001; Tran and Kang 2013). In urbanised areas various technical solutions for managing rainwater are used more and more frequently, but there is still a deficit of research work documenting the efficiency and reasonableness of using such solutions in conditions of erosion. Incorrect selection, installation and use of the system may result in unsatisfactory operation and even a negative impact on the adjoining grounds.

This paper aims to assess the operation of the system of managing rainwater from the area of the Lublin Wholesale Market and fuel station located in the metropolitan area of Lublin (south-eastern Poland). The analysed rainwater harvesting and treatment system (RHTS) was commissioned in 1999. It combines technical and semi-natural solutions.

Page 2/20 
It is located within a loess area at considerable risk of water erosion. Many components are made of native soil, which in unfavourable conditions can reduce the reliability and safety of work. The basic elements of rainwater system are earthen reservoirs. The system is supplemented by arc sieve, underground sewers, wells, safety overflows, weirs, separators and a treated water intake. Rainwater is transported solely by gravity. The main tasks of the reservoirs include reduction of rainwater run-off (storage, infiltration, evapotranspiration) and reduction of the concentration of pollutants. Rainwater treatment is carried out in a water and soil environment, mostly using natural processes sedimentation, flotation, dilution, mixing, sorption, filtration, oxygenation, chemical reactions and biological phenomena. The treatment technology was selected based on high availability of free space, relatively low costs of investment and operation, possibility of using self-purification and gravity flows (energy savings), as well as the possibility of reusing the post-treatment water in the direct neighbourhood of the reservoirs (savings of tap water, reduced cost of transport). Studies carried out in 2000-2020 determined, among other parameters, the quality of rainwater accumulated in the reservoirs and the water treatment efficiency. Based on numerous field observations an evaluation of the basic technical and operating parameters of the facility at different stages of its operation was carried out.

\section{Materials And Methods}

\subsection{General conditions}

The studied facility is located in south-eastern Poland within the Lublin Upland macroregion. The territory is characterised by varied loess relief with height differences of several tens of metres and large drops. The presence of loess soil, terrain relief and method of its development are conducive to water and air erosion. This area is located within the reach of the protective Major Groundwater Reservoir "Niecka Lubelska”. This is one of the largest natural useful groundwater reservoirs in Poland with a high level of risk. Therefore, rational water and sewage management is required within its limits (Mikołajków and Sadurski 2017).

The Lublin Wholesale Market (LWM), the fuel station and the related sewerage system were commissioned in 1999. The activity of LWM is mainly based on trade, services (e.g. road transport, goods storage) or food processing. On the other hand, fuel station sells motor fuel and retail products. These facilities are located at national road, right behind the northern boundary of the city of Lublin. They cover an area of $23.6 \mathrm{ha}$, of which $19.8 \mathrm{ha}$ is a sealed surface. The predominant structures are flat market squares and training yards, car parks, carriageways, pavements and roofs. The drained facility is located on the top part of the upland. From the south and east it is enclosed by dry erosion valleys (Fig. 1).

A separate sewerage system is placed within the LWM and fuel station area. Rainwater is disposed of into the reservoirs which are the subject of the study. The rainwater sewerage system consists of the main interceptor with a diameter of $1000 \mathrm{~mm}$ to which lateral sewers with a diameter of up to $400 \mathrm{~mm}$ are connected. The system is fitted with inspection chambers and street inlets with small settlers. Rainwater runoff from the area of the fuel station is pre-treated in a sand trap (HEK-EN 4000) and oil derivatives separator (SuperPEK NS 25) before it is transferred into the LWM sewerage system. The whole system is based on gravity flow. This is possible thanks to using the right longitudinal and transverse slopes and differences in the elevation of respective components. The analysed reservoir system was built in the bottom of a dry erosion valley connecting to the valley of the Bystrzyca - the main river in Lublin city (Fig. 1). The base soil is composed of silt and silty till. A gravel road runs on the bottom of the valley in the direct neighbourhood of the reservoirs. There are also numerous small farms nearby.

\subsection{RHTS - variant 1 (1999-2014)}

In 1999-2014 the RHTS was made of an arc sieve and two earthen reservoirs - sealed settler (area 0.43 ha, capacity $\left.3,900 \mathrm{~m}^{3}\right)$ and infiltration reservoir $\left(0.60 \mathrm{ha}, 5,600 \mathrm{~m}^{3}\right)$ (Fig. 2). Active depths were about $1.0 \mathrm{~m}$. 
The equipment was designed for rainfall $p=50 \%$ (probability of occurrence) lasting for 180 minutes with an intensity of $18 \mathrm{dm}^{3} \cdot \mathrm{ha}^{-1} \cdot \mathrm{s}^{-1}$ and single-time influx volume of about $3,750 \mathrm{~m}^{3}$. With the average annual precipitation sum (598 mm) during the year $141,130 \mathrm{~m}^{3}$ of water falls on the surface of the market ( $23.6 \mathrm{ha}$ ). The arc sieve of US-910z type was placed in the escarpment (border of the square), inside a reinforced concrete chamber. The cascade solution allows bringing rainwater down from the elevation of 196.8 to $192.7 \mathrm{~m}$ asl. During the straining process the sieve retains particles larger than $5 \mathrm{~mm}$ (e.g. packaging, leaves, residues of fruits and vegetables). The maximum capacity of the sieve is $60 \mathrm{~m}^{3} \cdot \mathrm{h}^{-1}$. The water free of larger solid contaminants was transported via pipelines to the weir chamber and then to the settler. In emergency situations water could be transferred directly to the infiltration reservoir skipping the settler (such an event did not occur during the study period). The bottom and slopes of the settler were lined with a bentomat (bentonite insulation) and reinforced with prefabricated strengthened concrete slabs. The settler was connected with the infiltration reservoir by downpipes with gate valves and safety overflow in the levee crown (Fig. 2). The overflow was automatic after the settler was overfilled. The infiltration reservoir was not equipped with seals. Its levees were made from native soil and covered with turf. Pre-treated rainwater was introduced into the soil through the bottom of the reservoir. The slopes of both reservoirs and the bottom of the infiltration reservoir were covered with aquatic plants supporting the treatment process. Behind the infiltration reservoir an additional absorptive surface was separated (grassland), to collect rainwater in case the reservoirs are overfilled. Water flowed through the safety overflow at the end of the reservoir (Fig. 2). In the initial period of the RHTS operation, rainwater pre-treated in the infiltration reservoir was reused for washing the squares and roads within the market. This solution contributed to saving tap water in the metropolitan area of Lublin that is deficient in that respect. Due to devastation of the intake, after a few years of operation of the facility return pumping of water was abandoned, which increased the risk of overfilling the reservoirs.

\subsection{RHTS - variant 2 (2014-2020)}

In connection with the increasing level of water in the settler and in the infiltration reservoir, deteriorating technical condition of respective facilities and the planned increase of the sealed surface of the LWM (increase in the forecast inflow of rainwater), in 2014 the RHTS was thoroughly modernised and expanded. A new large infiltration reservoir was built on the western side of the settler and a number of new reinforcing elements were added (Fig. 3). The only structure to which no changes were made was the arc sieve chamber.

In the case of the existing infiltration reservoir (eastern side) the bottom area was increased by 0.25 ha and the capacity by $2,200 \mathrm{~m}^{3}$ (dimensions after the expansion: area of the basin $0.85 \mathrm{ha}$, capacity of $7,800 \mathrm{~m}^{3}$ ). The new infiltration reservoir (western side) has an area of 1.00 ha and capacity of $9,000 \mathrm{~m}^{3}$. Active depths of the reservoirs did not change and are about $1.0 \mathrm{~m}$. The infiltration reservoirs have no technical reinforcement and are not sealed. The levees and bottoms were made from local soil. They were covered with humus and grass was sown over them. During the modernisation new safety overflows were built between the settler and the infiltration reservoirs (Fig. 3). They were reinforced with prefabricated concrete JOMB slabs. The overflow was also made in the levee at the end of the eastern reservoir. If the water level in the reservoir is close to overfilling, the overflow should direct excess water to the valley according to the periodic run-off of surface waters. Following the expansion of RHTS no water flowing over the safety overflows was observed. Rainwater is transferred from the settler to the infiltration reservoirs via pipelines installed in the levees. They are equipped with oil derivatives separators and outlet weirs. In addition, infiltration reservoirs were connected by means of a pipeline for the purposes of aligning the water pressure and levels if necessary (Fig. 3). Next to the eastern infiltration reservoir a pumping station building was erected to supply the designed artificial rain system in the future (e.g. irrigation of the energy crops plantation).

\subsection{Climatic conditions}

Data concerning selected climatic conditions in the study area was retrieved from elaborations prepared by Statistics Poland in Warsaw. Special attention was paid to periods during which rainwater runoff quality was analysed. The first 
of them covers the years 2008-2010 - before the modernisation and expansion of RHTS and the second 2016-2018after modernisation and expansion. Analyses of climatic conditions were mainly based on atmospheric precipitation sums and air temperature values responsible for the emergence and volume of rainwater runoffs. Values of those parameters were compared with data pertaining to a multi-annual period (1971-2010).

\subsection{Field observations}

During the studies about one thousand photographs of respective units and sections of the RHTS and the adjoining grounds were taken. In addition, the longitudinal and transverse profiles of a section of the valley in which the RHTS is located were determined. It was possible based on geodetic measurements. A GNSS Topcon HiPer V receiver and a Topcon FC-2600 controller were used. The quantity and quality of erosion changes were recorded and documented. A graphical presentation of the results was prepared using CorelDRAW and appropriate cartographic materials (topographic maps and orthophotomaps).

\subsection{Water sampling and analysis}

Analyses of the physico-chemical properties of rainwater accumulated in the reservoirs of RHTS were carried out seasonally (in total 24 measurement dates). Samples were taken using a bailer in half of the length of the reservoirs during rainless weather. Water was tested at the Water and Wastewater Laboratory of the University of Life Sciences in Lublin. The following devices were used: WTW MPM 2010, WTW Multi 340i, and Slandi LF 205. The following parameters were determined in the samples: electrolytic conductivity (by conductometry), $\mathrm{pH}$ (by potentiometry), total suspended solids (by drying and weighing), dissolved oxygen $\left(\mathrm{O}_{2}\right), \mathrm{BOD}_{5}$ (by dilution), $\mathrm{COD}$ (by dichromate method), ammonium ions $\left(\mathrm{NH}_{4}{ }^{+}\right)$, nitrates $\left(\mathrm{NO}_{3}{ }^{-}\right)$, nitrites $\left(\mathrm{NO}_{2}{ }^{-}\right)$, phosphates $\left(\mathrm{PO}_{4}{ }^{3-}\right)$, sulphates $\left(\mathrm{SO}_{4}{ }^{2-}\right)$, iron $\left(\mathrm{Fe}^{3+}\right)$, potassium $\left(\mathrm{K}^{+}\right)$, and chlorides $\left(\mathrm{Cl}^{-}\right)$(photometric determination). In addition, field measurements of water temperature were carried out. In evaluating the quality of water the extreme and mean values of the analysed indicators were determined for all checkpoints. Statistical variability of the results was based on the standard deviation and the coefficient of variation. Non-parametric Wilcoxon and Mann-Whitney tests made it possible to determine the significance of differences in the quality of rainwater in the settler before the modernisation (2008-2010) and after the modernisation of RHTS (20162018), comparison of the content of pollutants in the settler and the infiltration reservoir in both variants (evaluation of treatment efficiency), as well as the degree of pollution of water and its treatment efficiency in the cold season (autumnwinter) and warm season (spring-summer). The choice of statistical tools depended, among other things, on the number of variables in comparable sets. The analyses were carried out for the level of significance $a=0.05$ and $a=0.10$. Furthermore, percentage differences in the content of pollutants were determined in various combinations.

\section{Results And Discussion}

\subsection{Analysis of climatic conditions}

Special attention was paid to periods during which rainwater runoff quality was analysed (Table 1). In the first period (2008-2010) the mean annual sum of precipitation was $96 \mathrm{~mm}$ higher than the multiannual average. In the second period (2016-2018) the mean annual precipitation was close to the mean annual precipitation in 1971-2010. Year 2010 was especially abundant in rainfall as the precipitation sum was $753 \mathrm{~mm}$. In May 2010 the highest monthly precipitation in the whole study period was recorded ( $170 \mathrm{~mm}-23 \%$ of annual precipitation). Monthly precipitation above $100 \mathrm{~mm}$ occurred almost exclusively in the warm season (April-September). In the study period the mean precipitation in the warm season was 48\% higher than in the cold season (October-March). In 2008-2010 annual precipitation sums grew successively (from 649 to $753 \mathrm{~mm}$ ), whereas in 2016-2018 they decreased (from 698 to 481 $\mathrm{mm}$ ). In 2018 total rainfall was $20 \%$ lower than the multiannual rainfall. At that time a hydrological drought occurred. In no month did the precipitation sum exceed $70 \mathrm{~mm}$. In that year exceptionally high air temperatures were also recorded. 
The mean annual temperature was $9.3^{\circ} \mathrm{C}$ and was higher than the multiannual average by as much as $1.6^{\circ} \mathrm{C}$. In the analysed periods considerable differences were observed between the minimum and maximum monthly precipitation (78 mm - 2008-2010 and $71 \mathrm{~mm}$ - 2016-2018). This could lead to large differences in the rainwater run-off directed to the tested retention reservoirs. Mean annual air temperatures were by $0.5(2008-2010)$ and by $1.1^{\circ} \mathrm{C}(2016-2018)$ higher than the multiannual average. In the first period mean annual temperatures successively decreased and in the second period they increased (the situation was reverse for annul precipitation sums). The phenomena most likely affected the rate of evapotranspiration and the volume of rainwater accumulated in the reservoirs. In the analysed periods the average temperature in the warm season was 15.5 , and in the cold season it was $1.5^{\circ} \mathrm{C}$. Large differences were observed between the minimum and maximum monthly temperatures.

Table 1

Monthly and annual precipitation sums and mean air temperature in the study period compared with average climatic conditions in a multiannual period (CSO 2009, 2010, 2011, 2017; SP 2018, 2019)

\begin{tabular}{|c|c|c|c|c|c|c|c|c|c|c|c|c|c|c|}
\hline Period & I & II & III & IV & V & VI & VII & VIII & IX & $x$ & XI & XII & I-XII & \\
\hline \multirow[t]{3}{*}{$\begin{array}{l}\text { Precipitation } \\
(\mathrm{mm})\end{array}$} & $\begin{array}{l}2008- \\
2010\end{array}$ & 30 & 28 & 52 & 27 & 105 & 81 & 83 & 74 & 78 & 53 & 44 & 38 & 694 \\
\hline & $\begin{array}{l}2016- \\
2018\end{array}$ & 25 & 37 & 42 & 46 & 39 & 49 & 96 & 42 & 51 & 82 & 34 & 54 & 597 \\
\hline & $\begin{array}{l}1971- \\
2010\end{array}$ & 32 & 30 & 37 & 39 & 63 & 69 & 82 & 69 & 63 & 43 & 38 & 33 & 598 \\
\hline \multirow[t]{3}{*}{$\begin{array}{l}\text { Temperature } \\
\left({ }^{\circ} \mathrm{C}\right)\end{array}$} & $\begin{array}{l}2008- \\
2010\end{array}$ & -3.9 & -0.8 & 2.3 & 9.4 & 13.1 & 16.8 & 19.4 & 18.6 & 13.0 & 7.2 & 5.2 & -2.0 & 8.2 \\
\hline & $\begin{array}{l}2016- \\
2018\end{array}$ & -3.4 & -0.9 & 2.8 & 9.6 & 14.9 & 18.1 & 19.0 & 19.0 & 14.7 & 8.5 & 3.1 & 0.5 & 8.8 \\
\hline & $\begin{array}{l}1971- \\
2010\end{array}$ & -3.1 & -2.0 & 2.0 & 8.0 & 13.5 & 16.1 & 18.5 & 17.7 & 13.0 & 7.8 & 3.0 & -1.6 & 7.7 \\
\hline
\end{tabular}

\subsection{Analysis of the RHTS operation - variant 1 (1999-2014)}

The first serious problems in the operation of the RHTS were noted five years after its construction. They were mostly connected with errors in the design, operational omissions and harmful activity of third parties. The facility was designed only for collecting rainwater from the area of the market and fuel station. However, during extremely large rainfall the infiltration reservoir was supplied with water flowing on the surface of the northern slope. The average slope inclination is $10 \%$, and its length reaches $60 \mathrm{~m}$. Surface run-offs were the carriers of soil erosion products (Fig. 4A). No levee or surrounding drainage ditch was constructed from the side of the steep slope. The design assumed that the turf and shrub cover of the slope will provide sufficient protection against uncontrolled surface run-off. Periodic turbidity and sedimentation of loess deposits additionally testify to the incorrect general evaluation of the conditions in pre-design studies. Given the large length and inclination of the slope, the existing plant cover was not sufficient. Due to the influx of clay particles to the infiltration reservoir its bottom was probably clogged and water infiltration into the soil base was reduced (Conley et al. 2020). As a result, the degree of filling the analysed reservoirs started growing dangerously (Fig. 4C) and the safety overflow located between them was more and more often flooded by stagnating water. In the case of both safety overflows deepening erosion damage was observed (Fig. 4B). Reinforcement of loess levees in the form of geomembrane and open-work concrete slabs was insufficient. In the long run it could lead to building collapse and flooding of adjoining grounds (Danka and Zhang 2015). 
A big problem was also the unlimited access of third parties to the analysed facility and the lack of relevant marking. The absence of fencing and monitoring resulted in devastation and theft of certain elements of equipment, e.g. submersible pump and platforms. An extreme irresponsibility was the use of the rainwater reservoirs for recreational purposes - e.g. for angling (Fig. 4D) and activities leading to earth loss in levees on the southern side (weakening of structures).

In 2008-2010 rainwater accumulated in the settler featured large differences in quality. High coefficients of variation exceeding 100\% were found for conductivity, suspended solids and $\mathrm{Cl}^{-}$(Table 2). A relatively high value of this parameter was also observed for $\mathrm{NO}_{3}{ }^{-}(91.3 \%)$. In other cases, it ranged from $7.1(\mathrm{pH})$ to $76.0 \%$ (temperature). Studies carried out in other rainwater management facilities also confirm a considerable variability in the quality of rainwater (Peng et al. 2016; Zubala 2018). This phenomenon is connected with the presence of many factors determining the degree of pollution of rainwater and rainwater run-offs. Significant factors include the variability of weather conditions, method of using the drained area or the rainwater management system. In the analysed rainwater system, for instance, a considerable improvement in the quality of water stored after long-lasting rainfall was observed. After the drained area had been flushed, clear liquid of relatively good quality was supplied to the site and had a diluting effect on rainwater from previous run-offs (Lee et al. 2002; Zubala 2018). On the other hand, the load of pollutants increased during thaw, which was a result of a strong accumulation of pollutants on the snow cover surface (Reinosdotter and Viklander 2005). 
Table 2

Characteristic values of rainwater quality indicators in settler (control point 1 ) and infiltration reservoir (control point 2 ) in 2008-2010 (statistical significance of differences in quality variables was determined for $a=0.05$ and $a=0.10-$

Wilcoxon test)

\begin{tabular}{|c|c|c|c|c|c|c|c|c|}
\hline Variables & $\begin{array}{l}\text { Control } \\
\text { point }\end{array}$ & $\begin{array}{l}\text { Minimal } \\
\text { value }\end{array}$ & $\begin{array}{l}\text { Maximum } \\
\text { value }\end{array}$ & Average & $\begin{array}{l}\text { Percentage } \\
\text { difference }\end{array}$ & $\begin{array}{l}\text { Standard } \\
\text { deviation }\end{array}$ & $\begin{array}{l}\text { Variation } \\
\text { coefficient }\end{array}$ & $\begin{array}{l}\text { Important } \\
\text { difference }\end{array}$ \\
\hline \multirow{2}{*}{$\begin{array}{l}\text { Temperature } \\
\left({ }^{\circ} \mathrm{C}\right)\end{array}$} & 1 & 0.5 & 25.0 & 12.2 & \multirow[t]{2}{*}{+0.3} & 9.3 & 76.0 & \multirow[t]{2}{*}{-} \\
\hline & 2 & 0.5 & 25.5 & 12.3 & & 9.4 & 76.7 & \\
\hline \multirow{2}{*}{$\begin{array}{l}\text { Conductivity } \\
\left(\mu \mathrm{S} \cdot \mathrm{cm}^{-1}\right)\end{array}$} & 1 & 54 & 1,730 & 447.8 & \multirow[t]{2}{*}{-28.1} & 481.7 & 107.6 & \multirow[t]{2}{*}{-} \\
\hline & 2 & 67 & 1,247 & 322.2 & & 321.7 & 99.8 & \\
\hline \multirow[t]{2}{*}{$\mathrm{pH}$} & 1 & 5.9 & 7.7 & 7.2 & \multirow[t]{2}{*}{+5.1} & 0.5 & 7.1 & \multirow{2}{*}{$\begin{array}{l}+ \\
(a=0.05)\end{array}$} \\
\hline & 2 & 5.9 & 9.3 & 7.6 & & 0.9 & 11.6 & \\
\hline \multirow{2}{*}{$\begin{array}{l}\text { Suspension } \\
\left(\mathrm{mg} \cdot \mathrm{dm}^{-3}\right)\end{array}$} & 1 & 8.4 & 144.4 & 29.0 & \multirow[t]{2}{*}{-43.4} & 38.1 & 131.5 & \multirow{2}{*}{$\begin{array}{l}+ \\
(a=0.05)\end{array}$} \\
\hline & 2 & 3.0 & 61.0 & 16.4 & & 15.5 & 94.6 & \\
\hline $\mathrm{O}_{2}$ & 1 & 4.0 & 9.0 & 6.9 & \multirow[t]{2}{*}{+31.9} & 1.4 & 19.6 & \multirow{2}{*}{$\begin{array}{l}+ \\
(a=0.05)\end{array}$} \\
\hline$\left(\mathrm{mg} \cdot \mathrm{dm}^{-3}\right)$ & 2 & 5.1 & 12.4 & 9.1 & & 2.1 & 23.5 & \\
\hline $\mathrm{BOD}_{5}$ & 1 & 5.2 & 7.5 & 6.1 & \multirow[t]{2}{*}{-23.0} & 0.7 & 11.8 & \multirow{2}{*}{$\begin{array}{l}+ \\
(a=0.10)\end{array}$} \\
\hline$\left(\mathrm{mg} \cdot \mathrm{dm}^{-3}\right)$ & 2 & 0.4 & 8.4 & 4.7 & & 2.2 & 47.5 & \\
\hline $\mathrm{COD}_{\mathrm{Cr}}$ & 1 & 14 & 53 & 30.9 & \multirow[t]{2}{*}{-23.7} & 11.4 & 36.9 & \multirow{2}{*}{$\begin{array}{l}+ \\
(a=0.05)\end{array}$} \\
\hline$\left(\mathrm{mg} \cdot \mathrm{dm}^{-3}\right)$ & 2 & 9 & 40 & 23.6 & & 10.4 & 44.3 & \\
\hline $\mathrm{NH}_{4}^{+}$ & 1 & 0.08 & 1.24 & 0.42 & \multirow[t]{2}{*}{-46.7} & 0.3 & 74.8 & \multirow{2}{*}{$\begin{array}{l}+ \\
(a=0.05)\end{array}$} \\
\hline$\left(\mathrm{mg} \cdot \mathrm{dm}^{-3}\right)$ & 2 & 0.04 & 0.49 & 0.22 & & 0.2 & 73.6 & \\
\hline $\mathrm{NO}_{3}^{-}$ & 1 & 0.09 & 4.38 & 1.41 & \multirow[t]{2}{*}{-41.0} & 1.3 & 91.3 & \multirow{2}{*}{$\begin{array}{l}+ \\
(a=0.10)\end{array}$} \\
\hline$\left(\mathrm{mg} \cdot \mathrm{dm}^{-3}\right)$ & 2 & 0.09 & 2.12 & 0.83 & & 0.6 & 77.5 & \\
\hline $\mathrm{NO}_{2}^{-}$ & 1 & 0.03 & 0.26 & 0.11 & \multirow[t]{2}{*}{-41.9} & 0.1 & 52.6 & \multirow{2}{*}{$\begin{array}{l}+ \\
(a=0.05)\end{array}$} \\
\hline$\left(\mathrm{mg} \cdot \mathrm{dm}^{-3}\right)$ & 2 & 0.03 & 0.16 & 0.06 & & 0.04 & 66.2 & \\
\hline $\mathrm{PO}_{4}^{3-}$ & 1 & 0.09 & 1.20 & 0.50 & \multirow[t]{2}{*}{-17.0} & 0.3 & 68.9 & \multirow[t]{2}{*}{ - } \\
\hline$\left(\mathrm{mg} \cdot \mathrm{dm}^{-3}\right)$ & 2 & 0.10 & 0.89 & 0.41 & & 0.3 & 74.2 & \\
\hline $\mathrm{SO}_{4}{ }^{2-}$ & 1 & 2 & 18 & 9.2 & \multirow[t]{2}{*}{-0.9} & 5.3 & 57.9 & \multirow[t]{2}{*}{-} \\
\hline$\left(\mathrm{mg} \cdot \mathrm{dm}^{-3}\right)$ & 2 & 3 & 24 & 9.1 & & 6.2 & 67.9 & \\
\hline $\mathrm{Fe}^{3+}$ & 1 & 0.20 & 0.90 & 0.46 & \multirow[t]{2}{*}{-45.7} & 0.2 & 51.4 & \multirow{2}{*}{$\begin{array}{l}+ \\
(a=0.05)\end{array}$} \\
\hline$\left(\mathrm{mg} \cdot \mathrm{dm}^{-3}\right)$ & 2 & 0.08 & 0.50 & 0.25 & & 0.1 & 46.7 & \\
\hline
\end{tabular}




\begin{tabular}{|lllllllll|}
\hline Variables & $\begin{array}{l}\text { Control } \\
\text { point }\end{array}$ & $\begin{array}{l}\text { Minimal } \\
\text { value }\end{array}$ & $\begin{array}{l}\text { Maximum } \\
\text { value }\end{array}$ & Average & $\begin{array}{l}\text { Percentage } \\
\text { difference }\end{array}$ & $\begin{array}{l}\text { Standard } \\
\text { deviation }\end{array}$ & $\begin{array}{l}\text { Variation } \\
\text { coefficient }\end{array}$ & $\begin{array}{l}\text { Important } \\
\text { difference }\end{array}$ \\
\hline $\mathrm{K}^{+}$ & 1 & 1.7 & 24.0 & 10.1 & -42.5 & 6.5 & 63.8 & + \\
$\left(\mathrm{mg} \cdot \mathrm{dm}^{-3}\right)$ & 2 & 1.9 & 10.1 & 5.8 & & 2.5 & 42.7 & $(\mathrm{a}=0.05)$ \\
\cline { 1 - 1 } & 1 & 2.8 & 210.0 & 56.0 & -34.8 & 70.9 & 126.5 & - \\
$\mathrm{Cl}^{-}$ & 2 & 5.1 & 140.0 & 36.5 & & 40.1 & 109.8 & \\
\hline
\end{tabular}

On most of the measurement dates rainwater accumulated in the settler was characterised by unsatisfactory quality. Ratios deteriorating the quality of water were primarily $\mathrm{BOD}_{5}, \mathrm{COD}$, and $\mathrm{PO}_{4}{ }^{3-}$ (Table 2 ). In about $50 \%$ of the analysed samples $\mathrm{BOD}_{5}$ exceeded $6.0 \mathrm{mg} \cdot \mathrm{dm}^{-3}$, and COD $30 \mathrm{mg} \cdot \mathrm{dm}^{-3}$. The results point to a relatively high load of organic pollutants in the settler (Dojlido 1995). Another problem was bottom sediments that had not been removed from the reservoir. Over ten years a 15-centimetre-thick layer of sediments accumulated on the bottom, which given the area of 0.43 ha results in a volume of $645 \mathrm{~m}^{3}$ (17\% of the capacity of the settler). In adverse thermal and oxygen conditions the presence of sediments contributed to secondary contamination of the stored rainwater - e.g. increase in turbidity due to resuspension or release of phosphorus in biochemical processes (Braskerud et al. 2005). Analyses of certain chemical and biochemical properties of sediments carried out in 2007 showed significant concentrations of organic carbon (on average $4,540.00 \mathrm{mg} \cdot \mathrm{kg}^{-1}$ ) and $\mathrm{NH}_{4}{ }^{+}$(on average $83.05 \mathrm{mg} \cdot \mathrm{kg}^{-1}$ ) in the settler (Zubala et al. 2007). They were several times larger than those found in the sediments in the infiltration reservoir. The content of $\mathrm{NO}_{3}{ }^{-}$in the sediments in both reservoirs was comparable and on average amounted to $90.09 \mathrm{mg} \cdot \mathrm{kg}^{-1}$. The sediments from the settler contained several times less $\mathrm{N}^{-\mathrm{NO}_{3}}{ }^{-}$than $\mathrm{N}-\mathrm{NH}_{4}{ }^{+}$, which was connected with dissimilatory nitrate reduction using denitrification pathway enzymes. When the concentrations of $\mathrm{O}_{2}$ are low, microorganisms use $\mathrm{NO}_{3}{ }^{-}$as acceptors of electrons to obtain energy from organic compounds. The considerable contamination of sediments in the settler was the relatively high activity of enzymes (on average: dehydrogenase $8.03 \mathrm{~cm}^{3} \mathrm{H}_{2} \cdot \mathrm{kg}^{-1} \cdot \mathrm{d}^{-1}$, phosphatase $69.86 \mathrm{mmol} \mathrm{PNP} \cdot \mathrm{kg}^{-1} \cdot \mathrm{h}^{-1}$, urease $15.10 \mathrm{mg} \mathrm{N}-\mathrm{NH}_{4}{ }^{+} \cdot \mathrm{kg}^{-1} \cdot \mathrm{h}^{-1}$, protease $22.27 \mathrm{mg}$ tyrosine $\left.\cdot \mathrm{kg}^{-1} \cdot \mathrm{h}^{-1}\right)$. Activity in sediments in the settler was several times higher than in sediments in the infiltration reservoir. The biosynthesis of enzymes induced by bacteria is stimulated by the presence of organic elements (Renella et al. 2002). Jiang et al. (2019) also showed that the activites of urease, protease, dehydrogenase and catalase increases in the bioretention cells under the impact of simulated rainfall.

The concentration of $\mathrm{PO}_{4}{ }^{3-}$ was two times higher than $1.0 \mathrm{mg} \cdot \mathrm{dm}^{-3}$ in rainwater in the settler. According to Yang and Toor (2017), $\mathrm{PO}_{4}{ }^{3-}$ in street runoff likely originates from erosion of soil particles and mineralization of organic materials. On one of the measurement dates a minimum concentration of dissolved oxygen $\left(4.0 \mathrm{mg} \cdot \mathrm{dm}^{-3}\right)$, maximum content of suspended solids $\left(144.4 \mathrm{mg} \cdot \mathrm{dm}^{-3}\right)$ and elevated temperature of the liquid $\left(19.5^{\circ} \mathrm{C}\right)$ were also noted. Other biogenic indicators $\left(\mathrm{NH}_{4}{ }^{+}, \mathrm{NO}_{3}{ }^{-}, \mathrm{NO}_{2}{ }^{-}\right)$did not reach alarming values. The mean concentrations ranged from $0.11\left(\mathrm{NO}_{2}{ }^{-}\right)$to 1.41 $\mathrm{mg} \cdot \mathrm{dm}^{-3}\left(\mathrm{NO}_{3}{ }^{-}\right)$(Table 1). The results can corroborate the suggestions of other authors claiming that risks posed by nutrients running off with rainwater from road facilities are relatively low (Gan et al. 2008; Song et al. 2019).

Despite increasing problems related to operation and design, a positive effect of the RHTS on the quality of rainwater runoff was observed in 2008-2010. Many significant differences were found in the level of contamination of rainwater accumulated in the settler and infiltration reservoir (Wilcoxon test). The average concentrations of suspended solids, $\mathrm{NH}_{4}{ }^{+}, \mathrm{NO}_{3}{ }^{-}, \mathrm{NO}_{2}{ }^{-}, \mathrm{Fe}^{3+}$ and $\mathrm{K}^{+}$in the infiltration reservoir were $41.0-46.7 \%$ lower than in the settler (Table 2). $\mathrm{NO}_{3}{ }^{-}$and $\mathrm{NO}_{2}{ }^{-}$were eliminated to a greater degree than in the rainwater reservoir studied by Ivanovsky et al. (2018). The opposite 
trend was observed for $\mathrm{NH}_{4}{ }^{+}$. Despite relatively high average reduction in $\mathrm{BOD}_{5}(23.0 \%)$ and $\mathrm{COD}(23.7 \%)$, those indicators reached alarming values in the infiltration reservoir on some measurement dates $\left(\mathrm{BOD}_{5}\right.$ mostly in cold seasons, and COD in warm seasons). This phenomenon could be a result of the presence of an internal source of organic contaminants such as decaying dead aquatic plants. On the other hand, positive concentrations of oxygen were observed for water accumulated in the infiltration reservoir. In comparison to the settler they were higher by as much as $31.9 \%$ (average saturation $9.1 \mathrm{mg} \cdot \mathrm{dm}^{-3}$ ). Oxygen is one of the most important components conditioning selfpurification processes in the aquatic environment (Braskerud et al. 2005). The $\mathrm{pH}$ values of the analysed water ranged between 5.9-9.3, with the average value being 7.4. Periodic alkalinization of rainwater run-offs was probably a result of the presence of alkaline silt, salinity and processes occurring in the bottom sediments (Degtjarenko 2016).

\subsection{Analysis of the RHTS operation - variant 2 (2014-2020)}

During the modernisation and expansion of the RHTS the northern edges of the reservoirs were not secured by levees and drainage ditches (Fig. 5A). A large risk of outwashing the products of erosion from the uncovered slope existed especially in the first months after the modernisation (lack of permanent plant cover). In addition, the steep slopes of the infiltration reservoirs were not initially secured. Rill and surface erosion occurred very quickly (Fig. 5B) and resulted in the accumulation of sediments at the foot of the slopes (shallowing of the reservoirs). The phenomena were particularly visible on the northern side after intensive rainfall - streams of water flowing at a large speed formed on the slope. Surface erosion processes had been observed to slow down since 2015 due to the fact that the analysed area became overgrown with grass. Afterwards, another very dangerous erosion phenomenon occurred posing a risk to adjoining grounds. In the bottom of the western infiltration reservoir a piping well started to form (Fig. 5C). This process may result in land subsidence near the rainwater reservoirs, for instance, on farms with single-family buildings or a busy national road (Fig. 1) (Bernatek-Jakiel and Poesen 2018). The presented data indicates that it is a big mistake not to sufficiently take into account the specific features of land at a risk of water erosion in investment processes and treating popular technical and design solutions as reliable in any conditions. Measures that must be taken in the analysed grounds include preventing the concentration of uncontrolled run-off of rainwater by applying adequate technical and biotechnical solutions and biological stabilisation (Zhang et al. 2014). Increasing the capacity of infiltration reservoirs minimized the risk of overloading the RHTS with rainwater and damaging the safety overflows due to erosion. On the other hand, after several years of hydrological drought the infiltration reservoirs were filled with water at a minimum level. Despite most of the rainwater being directed from the settler to the eastern infiltration reservoir, throughout the whole term of the observation the water intake was located above the level of the stored water (Fig. 5D). In such conditions the functioning of the artificial rain system and the energy crop plantation, if any, will not be possible.

In 2016-2018 rainwater accumulated in the settler was characterised by larger differences in quality than in 20082010. High coefficient of variation, close to or exceeding $100 \%$, were found for conductivity, $\mathrm{COD}, \mathrm{NH}_{4}{ }^{+}, \mathrm{NO}_{3}{ }^{-}, \mathrm{PO}_{4}{ }^{3-}, \mathrm{K}^{+}$ and $\mathrm{Cl}^{-}$(Table 3). 
Table 3

Characteristic values of rainwater quality indicators in settler (control point 1) and infiltration reservoirs (control point 2 ) in 2016-2018 (statistical significance of differences in quality variables was determined for $a=0.05$ and $a=0.10-$

Wilcoxon test)

\begin{tabular}{|c|c|c|c|c|c|c|c|c|}
\hline Variables & $\begin{array}{l}\text { Control } \\
\text { point }\end{array}$ & $\begin{array}{l}\text { Minimal } \\
\text { value }\end{array}$ & $\begin{array}{l}\text { Maximum } \\
\text { value }\end{array}$ & Average & $\begin{array}{l}\text { Percentage } \\
\text { difference }\end{array}$ & $\begin{array}{l}\text { Standard } \\
\text { deviation }\end{array}$ & $\begin{array}{l}\text { Variation } \\
\text { coefficient }\end{array}$ & $\begin{array}{l}\text { Important } \\
\text { difference }\end{array}$ \\
\hline \multirow{2}{*}{$\begin{array}{l}\text { Temperature } \\
\left({ }^{\circ} \mathrm{C}\right)\end{array}$} & 1 & 1.5 & 26.0 & 13.1 & \multirow[t]{2}{*}{+2.2} & 8.7 & 66.4 & \multirow[t]{2}{*}{ - } \\
\hline & $2^{a}$ & 2.3 & 26.8 & 13.4 & & 8.7 & 65.0 & \\
\hline \multirow{2}{*}{$\begin{array}{l}\text { Conductivity } \\
\left(\mu \mathrm{S} \cdot \mathrm{cm}^{-1}\right)\end{array}$} & 1 & 121 & 2,360 & 670.3 & \multirow[t]{2}{*}{-26.7} & 619.9 & 92.5 & \multirow{2}{*}{$\begin{array}{l}+ \\
(a=0.05)\end{array}$} \\
\hline & 2 & 106 & 1,967 & 491.2 & & 681.4 & 138.7 & \\
\hline \multirow[t]{2}{*}{$\mathrm{pH}$} & 1 & 6.5 & 9.6 & 7.5 & \multirow[t]{2}{*}{+5.5} & 0.9 & 11.8 & \multirow{2}{*}{$\begin{array}{l}+ \\
(a=0.10)\end{array}$} \\
\hline & 2 & 6.7 & 8.6 & 7.9 & & 0.6 & 7.4 & \\
\hline \multirow{2}{*}{$\begin{array}{l}\text { Suspension } \\
\left(\mathrm{mg} \cdot \mathrm{dm}^{-3}\right)\end{array}$} & 1 & 4.0 & 18.2 & 10.2 & \multirow[t]{2}{*}{-25.6} & 5.4 & 53.2 & \multirow{2}{*}{$\begin{array}{l}+ \\
(a=0.10)\end{array}$} \\
\hline & 2 & 2.5 & 16.7 & 7.6 & & 3.6 & 48.2 & \\
\hline $\mathrm{O}_{2}$ & 1 & 3.9 & 12.9 & 9.1 & \multirow[t]{2}{*}{+7.6} & 2.7 & 29.7 & \multirow[t]{2}{*}{ - } \\
\hline$\left(\mathrm{mg} \cdot \mathrm{dm}^{-3}\right)$ & 2 & 6.1 & 12.4 & 9.8 & & 1.8 & 18.9 & \\
\hline $\mathrm{BOD}_{5}$ & 1 & 2.4 & 8.4 & 5.6 & \multirow[t]{2}{*}{+1.4} & 1.9 & 34.4 & \multirow[t]{2}{*}{ - } \\
\hline$\left(\mathrm{mg} \cdot \mathrm{dm}^{-3}\right)$ & 2 & 3.4 & 8.5 & 5.7 & & 1.9 & 34.2 & \\
\hline $\mathrm{COD}_{\mathrm{Cr}}$ & 1 & 18 & 165 & 52.7 & \multirow[t]{2}{*}{+6.2} & 50.0 & 95.0 & \multirow[t]{2}{*}{-} \\
\hline$\left(\mathrm{mg} \cdot \mathrm{dm}^{-3}\right)$ & 2 & 8 & 162 & 55.9 & & 50.5 & 90.4 & \\
\hline $\mathrm{NH}_{4}^{+}$ & 1 & 0.04 & 0.63 & 0.18 & \multirow[t]{2}{*}{-37.0} & 0.2 & 115.0 & \multirow[t]{2}{*}{ - } \\
\hline$\left(\mathrm{mg} \cdot \mathrm{dm}^{-3}\right)$ & 2 & 0.05 & 0.35 & 0.11 & & 0.1 & 79.2 & \\
\hline $\mathrm{NO}_{3}^{-}$ & 1 & 0.10 & 1.81 & 0.67 & \multirow[t]{2}{*}{-33.6} & 0.6 & 89.7 & \multirow{2}{*}{$\begin{array}{l}+ \\
(a=0.05)\end{array}$} \\
\hline$\left(\mathrm{mg} \cdot \mathrm{dm}^{-3}\right)$ & 2 & 0.09 & 1.73 & 0.44 & & 0.5 & 119.6 & \\
\hline $\mathrm{NO}_{2}^{-}$ & 1 & 0.03 & 0.26 & 0.09 & \multirow[t]{2}{*}{-29.9} & 0.1 & 72.4 & \multirow{2}{*}{$\begin{array}{l}+ \\
(a=0.10)\end{array}$} \\
\hline$\left(\mathrm{mg} \cdot \mathrm{dm}^{-3}\right)$ & 2 & 0.01 & 0.28 & 0.06 & & 0.1 & 114.6 & \\
\hline $\mathrm{PO}_{4}{ }^{3-}$ & 1 & 0.02 & 1.22 & 0.23 & \multirow[t]{2}{*}{-65.0} & 0.4 & 163.6 & \multirow[t]{2}{*}{-} \\
\hline$\left(\mathrm{mg} \cdot \mathrm{dm}^{-3}\right)$ & 2 & 0.02 & 0.18 & 0.08 & & 0.1 & 76.8 & \\
\hline $\mathrm{SO}_{4}{ }^{2-}$ & 1 & 1 & 20 & 7.8 & \multirow[t]{2}{*}{-13.8} & 5.9 & 75.4 & \multirow[t]{2}{*}{-} \\
\hline$\left(\mathrm{mg} \cdot \mathrm{dm}^{-3}\right)$ & 2 & 1 & 16 & 6.8 & & 5.1 & 76.2 & \\
\hline $\mathrm{Fe}^{3+}$ & 1 & 0.21 & 1.16 & 0.66 & -7.8 & 0.4 & 54.5 & - \\
\hline
\end{tabular}




\begin{tabular}{|lllllllll|}
\hline Variables & $\begin{array}{l}\text { Control } \\
\text { point }\end{array}$ & $\begin{array}{l}\text { Minimal } \\
\text { value }\end{array}$ & $\begin{array}{l}\text { Maximum } \\
\text { value }\end{array}$ & Average & $\begin{array}{l}\text { Percentage } \\
\text { difference }\end{array}$ & $\begin{array}{l}\text { Standard } \\
\text { deviation }\end{array}$ & $\begin{array}{l}\text { Variation } \\
\text { coefficient }\end{array}$ & $\begin{array}{l}\text { Important } \\
\text { difference }\end{array}$ \\
\hline & 2 & 0.20 & 1.06 & 0.61 & & 0.3 & 48.9 & \\
$\mathrm{~K}^{+}$ & 1 & 1.3 & 44.8 & 7.8 & -63.8 & 12.7 & 162.6 & - \\
$\left(\mathrm{mg} \cdot \mathrm{dm}^{-3}\right)$ & 2 & 1.4 & 6.3 & 2.8 & & 1.9 & 65.8 & \\
\hline $\mathrm{Cl}^{-}$ & 1 & 3.9 & 82.4 & 31.1 & -19.9 & 29.7 & 95.3 & - \\
$\left(\mathrm{mg} \cdot \mathrm{dm}^{-3}\right)$ & 2 & 3.9 & 79.5 & 24.9 & & 24.3 & 97.4 & \\
\hline
\end{tabular}

Statistical analyses showed significant differences between the quality of rainwater in the settler in the years 20082010 and 2016-2018 (Mann-Whitney test). In the second period an improvement was observed in the quality of the liquid accumulated in the settler, which was evidenced by decreased concentrations of $\mathrm{NH}_{4}{ }^{+}, \mathrm{PO}_{4}{ }^{3-}, \mathrm{K}^{+}(\mathrm{a}=0.05)$ and suspended solids $(a=0.10)$. Differences in the mean values of these variables amounted to $57.1,54.5,22.8$ and $64.9 \%$ respectively (Tables 2 and 3). In addition, an increase of $31.6 \%$ in the mean concentration of dissolved oxygen was noted. The reason behind the positive changes was the removal of sediments from the bottom of the settler and more efficient removal of solid contaminants from the drained surface of the market in rainless periods (Hernández-Crespo et al. 2019). The simultaneous decrease in the content of suspended solids and nutrients can testify to a strong relationship between those components, and this thesis was supported by the studies of other authors (Vaze and Chiew 2004).

Similar to 2008-2010, water in the settler was characterised by high oxygen demand (Table 3). In subsequent years, the level of oxygen saturation of water in the settler decreased from $10.1 \mathrm{mg} \cdot \mathrm{dm}^{-3}$ (2016) to $7.2 \mathrm{mg} \cdot \mathrm{dm}^{-3}$ (2018). This phenomenon was connected with an increase in mean annual air temperatures, decrease in atmospheric precipitation (Table 1 ) and increased heating of water in the reservoir. Elevated temperatures did not foster the natural solubility of oxygen in water (Dojlido 1995). In the case of oxygen deficits and increased contamination with nutrients, floating wetland treatment plants (Samal et al. 2019) or mechanical and chemical aeration of water should be used as early as this stage of treatment (Imhoff and Imhoff 2006).

In 2016-2018 as many as 70\% of the analysed water quality indicators showed lower average values in the infiltration reservoirs than in the settler. However, the results of the Wilcoxon test corroborated the existence of statistically significant differences only for conductivity, suspended solids, $\mathrm{NO}_{3}{ }^{-}, \mathrm{NO}_{2}{ }^{-}$(decrease in value by $25.6-33.6 \%$ ) and $\mathrm{pH}$ (increase in value by 5.5\%) (Table 3). To compare, in 2008-2010 a different distribution of values was found for twice as many variables of water quality. A relatively lower treatment efficiency in 2016-2018 noted for some indicators was connected with their decreased concentration in the settler in that period (lower initial concentrations) and small differences in the degree of contamination of rainwater in infiltration reservoirs in both variants of the RHTS. The MannWhitney statistical test showed that the infiltration reservoirs in variant 2 were less loaded with suspended solids (difference 53.8\%), $\mathrm{NH}_{4}{ }^{+}(49.3 \%), \mathrm{PO}_{4}{ }^{3-}(80.8 \%)$ and $\mathrm{K}^{+}(51.4 \%)$ than the infiltration reservoir in variant 1 (Tables 2 and 3). In 2016-2018 in the infiltration reservoirs a considerable increase in the concentration of $\mathrm{Fe}^{3+}$ was noted in comparison to the infiltration reservoir in 2008-2010 (difference 144.5\%). During the modernisation of the RHTS a layer of subsoil rich in iron compounds reduced and activated due to long-lasting contact with water could be uncovered (Kabata-Pendias and Pendias 1993). In turn, an increased content of iron resulted in a considerable decrease in the 
concentration of $\mathrm{PO}_{4}{ }^{3-}$ in the water after treatment, which should be deemed positive. Reactions of iron with phosphate ions are commonly used in the processes of chemical treatment of municipal sewage (Wan et al. 2008). In the infiltration reservoirs elevated $\mathrm{BOD}_{5}$ and $\mathrm{COD}$ continued to be observed. The average value of the second indicator in 2016-2018 was as high as $55.9 \mathrm{mg} \cdot \mathrm{dm}^{-3}$ (Table 3).

The operation of RHTS in a moderate climate zone partially depends on the weather conditions in two seasons - the cold and warm season. In cold seasons (autumn-winter) the quality of water in the settler was observed to deteriorate, which is corroborated by the results of the Mann-Whitney test. At that time, an increase was observed in values such as conductivity (57.1\%), nitrate ions (36.1-62.1\%) and $\mathrm{Cl}^{-}$(69.5\%). The contaminants load considerably increased during melt-water run-offs. On every date on which a considerable leap in the concentration of $\mathrm{Cl}^{-}$was observed, the value of conductivity was also increased. In $25 \%$ of samples collected in the cold season the value of conductivity considerably exceeded $1,000 \mu \mathrm{S} \cdot \mathrm{cm}^{-1}$, which testifies to a high rate of mineralisation of the water. In Poland sodium chloride is commonly used for preventing slipperiness of snow-covered road infrastructure. Disposing of such rainwater into receiving water bodies could increase their salinity (Corsi et al. 2015). High concentrations of salt disturb the uptake of water and nutrients by plants leading to their weakening and drying out. It also has a lethal effect on many microorganisms and decelerates the process of mineralisation of organic pollutants. In cold seasons the concentration of nutrients in the treated rainwater runoff was nearly always increased compared to the situation in warm seasons. During the vegetation period the producers grew intensively, which increased the assimilation of nitrogen from water and sludge as well as reduced the influx of these pollutants from the catchment basin (Birgand et al. 2007). Similar trends in changes of the degree of contamination of water in respective six-month periods were also observed in the infiltration reservoirs. It was observed for conductivity (difference $46.5 \%), \mathrm{NO}_{3}{ }^{-}(56.1 \%), \mathrm{Fe}^{3+}(50.2 \%)$ and $\mathrm{Cl}^{-}(55.6 \%)$. In addition, in the infiltration reservoirs the content of $\mathrm{O}_{2}$ was observed to decrease significantly (difference 22.9\%) and the COD increased $(25.5 \%)$ in warm seasons.

Due to the relatively good quality of the water after treatment, it can be used for commercial purposes within the wholesale market. The condition is the rearrangement of the water intake in the infiltration reservoir (lower drainage elevation). Water can be used for irrigating energy crops growing on the surface of the northern slope (about 3 ha) adjoining the rainwater reservoirs. The project would provide the ultimate management of rainwater runoff (including after-treatment), production of energy biomass and protection of the slope surface against erosion. Some authors have demonstrated that integrated management of rainwater is associated with big economic and environmental benefits (Matos et al. 2015; Mitchell et al. 2007).

\section{Conclusions}

The condition for stable and efficient operation of large RHTSs in loess areas at a risk of erosion, is their adequate design, construction and use. Failing to take specific features of erosion-affected areas into account in the life cycles of systems based on earthen reservoirs can result in defects and, as a consequence, pose a risk to adjoining grounds.

Particular attention must be paid to effective protection of steep slopes, escarpments and elements through which water often flows. Excessive transfer of rainwater between respective facilities in the gravity treatment systems can be prevented by designing sufficiently large active capacities of respective reservoirs, reducing clogging of the bottoms of the infiltrating basins and increasing the use of water after treatment for commercial purposes.

Despite design and operational faults being found, the analysed RHTS had a beneficial effect on the quality of water. The values were considerably decreased for: conductivity, suspended solids, mineral forms of nitrogen, iron and potassium. At all stages of treatment, the concentration of dissolved oxygen maintained a satisfactory level. In the first variant of the RHTS (active capacity $9500 \mathrm{~m}^{3}$ ) a considerable hydraulic load and higher contamination of water in the 
settler was observed in comparison to the second variant $\left(20700 \mathrm{~m}^{3}\right)$. Due to a worse initial quality of water in the first variant of the RHTS (settler) and insignificant differences in the level of contamination of water in the infiltration reservoirs in both variants, the water treatment efficiency was normally higher before the modernisation. The expansion of the rainwater system led to uncovering of soil layers rich in iron compounds. Consequently, the concentration of iron in water in the infiltration reservoirs increased, which further led to a considerable decrease in the content of phosphates. The load on the analysed facility increased and the water treatment efficiency decreased in the cold season. This was caused by strongly contaminated melt-water run-off and limited share of autotrophs in the treatment processes. On the other hand, a significant improvement was observed in the quality of stored water after long-lasting rainfall (inflow of clear rainwater from the flushed drained area).

The relatively good quality of rainwater runoff after treatment makes it possible to use it for commercial purposes, which is in line with the concept of sustainable use of water resources. The most reasonable solution seems to create and irrigate a plantation of energy crops on the slope between the rainwater reservoirs and the drained area. The implementation of this project would facilitate the ultimate management of accumulated rainwater and controlled protection of the steep slope against erosion.

\section{Declarations}

Acknowledgments The author would like to thank the University of Life Sciences in Lublin for financial support (statutory activity).

Funding The author has not received support from any organization for the submitted work.

Financial interests The author has no relevant financial or non-financial interests to disclose.

Conflicts of interest/Competing interests The author declares that he has no conflict of interest.

Availability of data and material Not applicable.

Code availability Not applicable.

Authors' contributions Not applicable.

\section{References}

1. Bernatek-Jakiel A, Poesen J (2018) Subsurface erosion by soil piping: significance and research needs. Earth-Sci Rev 185:1107-1128. https://doi.org/10.1016/j.earscirev.2018.08.006

2. Birgand FR, Skaggs RW, Chescheir GM, Gilliam JW (2007) Nitrogen removal in streams of agricultural catchments a literature review. Crit Rev Environ Sci Technol 37(5):381-487. https://doi.org/10.1080/10643380600966426

3. Braskerud BC, Hartnik T, Løvstad $\varnothing ~(2005)$ The effect of the redox-potential on the retention of phosphorus in a small constructed wetland. Water Sci Technol 51(3-4):127-134. https://doi.org/10.2166/wst.2005.0583

4. Conley G, Beck N, Riihimaki CA, Tanner M (2020) Quantifying clogging patterns of infiltration systems to improve urban stormwater pollution reduction estimates. Water Res X 7:100049.

https://doi.org/10.1016/j.wroa.2020.100049

5. Corsi SR, De Cicco LA, Lutz MA, Hirsch RM (2015) River chloride trends in snow-affected urban watersheds: increasing concentrations outpace urban growth rate and are common among all seasons. Sci Total Environ 508:488-497. https://doi.org/ 10.1016/j.scitotenv.2014.12.012

Page $14 / 20$ 
6. CSO (Central Statistical Office) (2009) Environment 2009. Statistical Information and Elaborations, Warsaw

7. CSO (Central Statistical Office) (2010) Environment 2010. Statistical Information and Elaborations, Warsaw

8. CSO (Central Statistical Office) (2011). Environment 2011. Statistical Information and Elaborations, Warsaw

9. CSO (Central Statistical Office) (2017) Environment 2017. Statistical Information and Elaborations, Warsaw

10. Danka J, Zhang LM (2015) Dike Failure Mechanisms and Breaching Parameters. J Geotech Geoenviron Eng 141(9):04015039. https://doi.org/10.1061/(ASCE)GT.1943-5606.0001335

11. Degtjarenko P (2016) Impacts of alkaline dust pollution on biodiversity of plants and lichens: from communities to genetic diversity. University of Tartu Press, Tartu

12. Dojlido J (1995) Chemistry of surface waters. Ekonomia i Środowisko, Białystok

13. Gan H, Zhuo M, Li D, Zhou Y (2008) Quality characterization and impact assessment of highway runoff in urban and rural area of Guangzhou, China. Environ Monit Assess 140(1-3):147-159. https://doi.org/10.1007/s10661007-9856-2

14. Geiger W, Dreiseitl H (2001) New methods of rainwater drainage. Oldenbourg Verlag, München

15. Hatt BE, Fletcher TD, Walsh CJ, Taylor SL (2004) The Influence of Urban Density and Drainage Infrastructure on the Concentrations and Loads of Pollutants in Small Streams. Environ Manage 34:112-124.

https://doi.org/10.1007/s00267-004-0221-8

16. Hernández-Crespo C, Fernández-Gonzalvo M, Martín M, Andrés-Doménech I (2019) Influence of rainfall intensity and pollution build-up levels on water quality and quantity response of permeable pavements. Sci Total Environ 684:303-313. https://doi.org/10.1016/j.scitotenv.2019.05.271

17. Imhoff K, Imhoff KR (2006) Handbook of urban drainage. Oldenbourg Industrieverlag, München

18. Ivanovsky A, Belles A, Criquet J, Dumoulin D, Noble P, Alary C, Billon G (2018) Assessment of the treatment efficiency of an urban stormwater pond and its impact on the natural downstream watercourse. J Environ Manag 226:120-130. https://doi.org/10.1016/j.jenvman.2018.08.015

19. Jiang C, Li J, Li H, Li Y (2019) Nitrogen retention and purification efficiency from rainfall runoff via retrofitted bioretention cells. Sep Purif Technol 220:25-32. https://doi.org/10.1016/j.seppur.2019.03.036

20. Kabata-Pendias A, Pendias H (1993) Biogeochemistry of trace elements. PWN, Warszawa

21. Lee JH, Bang KW, Ketchum LH, Choe JS, Yu MJ (2002) First flush analysis of urban storm runoff. Sci Total Environ 293:163-175. https://doi.org/10.1016/s0048-9697(02)00006-2

22. Liu A, Li D, Liu L, Guan Y (2014) Understanding the Role of Urban Road Surface Characteristics in influencing Stormwater Quality. Water Resour Manag 28:5217-5229. https://doi.org/10.1007/s11269-014-0788-7

23. Maniquiz-Redillas MC, Geronimo FKF, Kim L-H (2014) Investigation on the effectiveness of pretreatment in stormwater management technologies. J Environ Sci 26(9):1824-1830. https://doi.org/10.1016/j.jes.2014.06.018

24. Matos C, Bentes I, Santos C, Imteaz M, Pereira S (2015) Economic Analysis of a Rainwater Harvesting System in a Commercial Building. Water Resour Manag 29:3971-3986. https://doi.org/10.1007/s11269-015-1040-9

25. Mikołajków J, Sadurski A (2017) Major groundwater reservoirs in Poland. Państwowy Instytut Geologiczny Państwowy Instytut Badawczy, Warszawa

26. Mitchell VG, Deletic A, Fletcher TD, Hatt BE, McCarthy DT (2007) Achieving multiple benefits from stormwater harvesting. Water Sci Technol 55(4):135-144. https://doi.org/10.2166/wst.2007.103

27. Peng H-Q, Liu Y, Wang H-W, Gao X-L, Ma L-M (2016) Event mean concentration and first flush effect from different drainage systems and functional areas during storms. Environ Sci Pollut Res 23:5390-5398.

https://doi.org/10.1007/s11356-015-5657-2

Page 15/20 
28. Renella G, Chaudri AM, Brookes PC (2002) Fresh additions of heavy metals do not model long-term effects on microbial biomass and activity. Soil Biol. Biochem. 34(1):121-124. https://doi.org/10.1016/S0038-0717(01)00150$\mathrm{X}$

29. Reinosdotter K, Viklander M (2005) A comparison of snow quality in two Swedish municipalities - Luleå and Sundsvall. Water Air Soil Pollut 167(1-4):3-16. https://doi.org/10.1007/s11270-005-8635-3

30. Samal K., Kar S, Trivedi S (2019) Ecological floating bed (EFB) for decontamination of polluted water bodies: Design, mechanism and performance. J Environ Manag 251:109550.

https://doi.org/10.1016/j.jenvman.2019.109550

31. Song H, Qin T, Wang J, Wong THF (2019) Characteristics of stormwater quality in Singapore catchments in 9 different types of land use. Water 11:2-10. https://doi.org/10.3390/w11051089

32. SP (Statistics Poland) (2018) Environment 2018. Statistical analyses, Warsaw

33. SP (Statistics Poland) (2019) Environment 2019. Statistical analyses, Warsaw

34. Tran D, Kang JH (2013) Optimal design of a hydrodynamic separator for treating runoff from roadways. J Environ Manag 116:1-9. https://doi.org/10.1016/j.jenvman.2012.11.036

35. Vaze J, Chiew F (2004) Nutrient loads associated with different sediment sizes in urban stormwater and surface pollutants. J Environ Eng 130:391-396. https://doi.org/10.1061/(ASCE)0733-9372(2004)130:4(391)

36. Wan J, Jiang X, Zhang TC, Hu J, Richter-Egger D, Feng X, Zhou A, Tao T (2018) The activated iron system for phosphorus recovery in aqueous environments. Chemosphere 196:153-160.

https://doi.org/10.1016/j.chemosphere.2017.12.140

37. Yang Y-Y, Toor GS (2017) Sources and mechanisms of nitrate and orthophosphate transport in urban stormwater runoff from residential catchments. Water Res 112:176-184. https://doi.org/10.1016/j.watres.2017.01.039

38. Zhang Q, Wang X, Hou P, Wan W, Li R, Ren Y, Ouyang Z (2014) Quality and seasonal variation of rainwater harvested from concrete, asphalt, ceramic tile and green roofs in Chongqing, China. J Environ Manag 132:178-187. https://doi.org/10.1016/j.jenvman.2013.11.009

39. Zhang X, Yu GQ, Li ZB, Li P (2014) Experimental Study on Slope Runoff, Erosion and Sediment under Different Vegetation Types. Water Resour Manag 28:2415-2433. https://doi.org/10.1007/s11269-014-0603-5

40. Zubala T (2018) Technical and natural conditions and operating efficiency of a municipal stormwater treatment plant. Environ Sci Pollut Res 25:952-962. https://doi.org/10.1007/s11356-017-0519-8

41. Zubala T, Bielińska EJ, Węgorek T, Głowacka A (2007) Ecochemistry of sludge from the rainwater treatment plant in the Lublin Wholesale Market, in: Szymański, K. (Ed.), Municipal waste management. Kom Chem Analit PAN, Koszalin, pp. 171-177

\section{Figures}




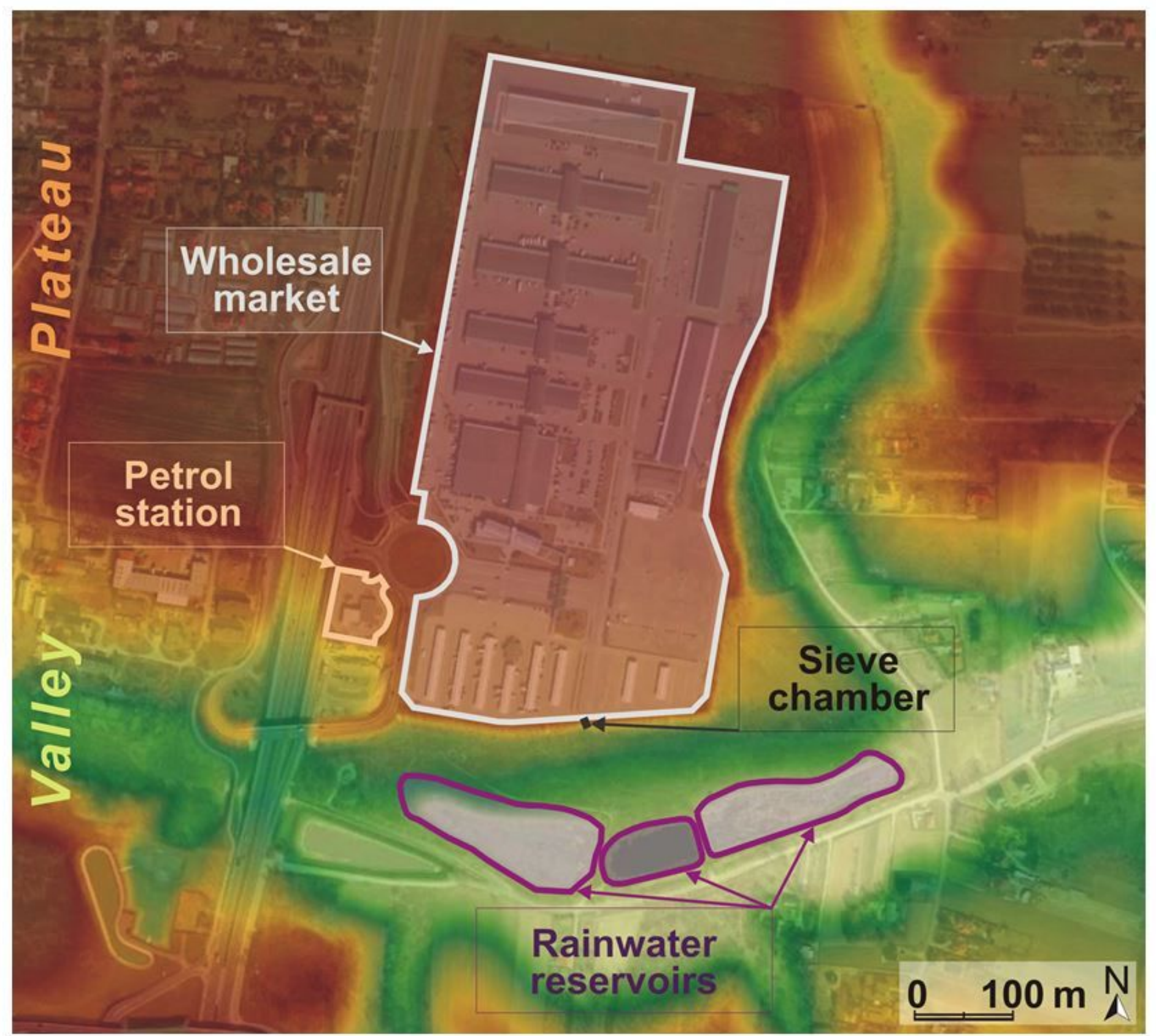

Figure 1

Location of the rainwater harvesting and treatment system (2020) 


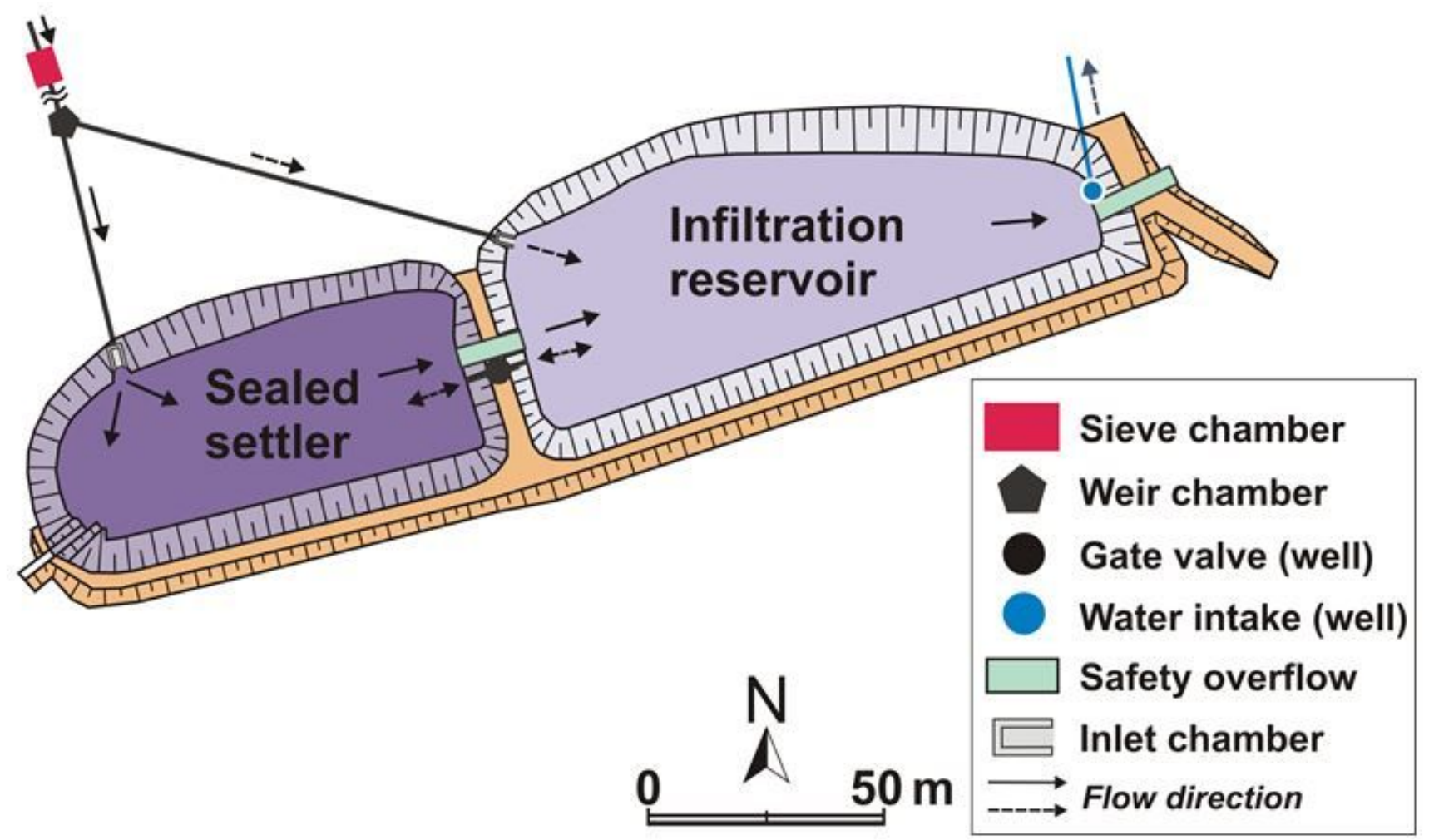

Figure 2

Rainwater harvesting and treatment system - variant 1 (1999-2014)

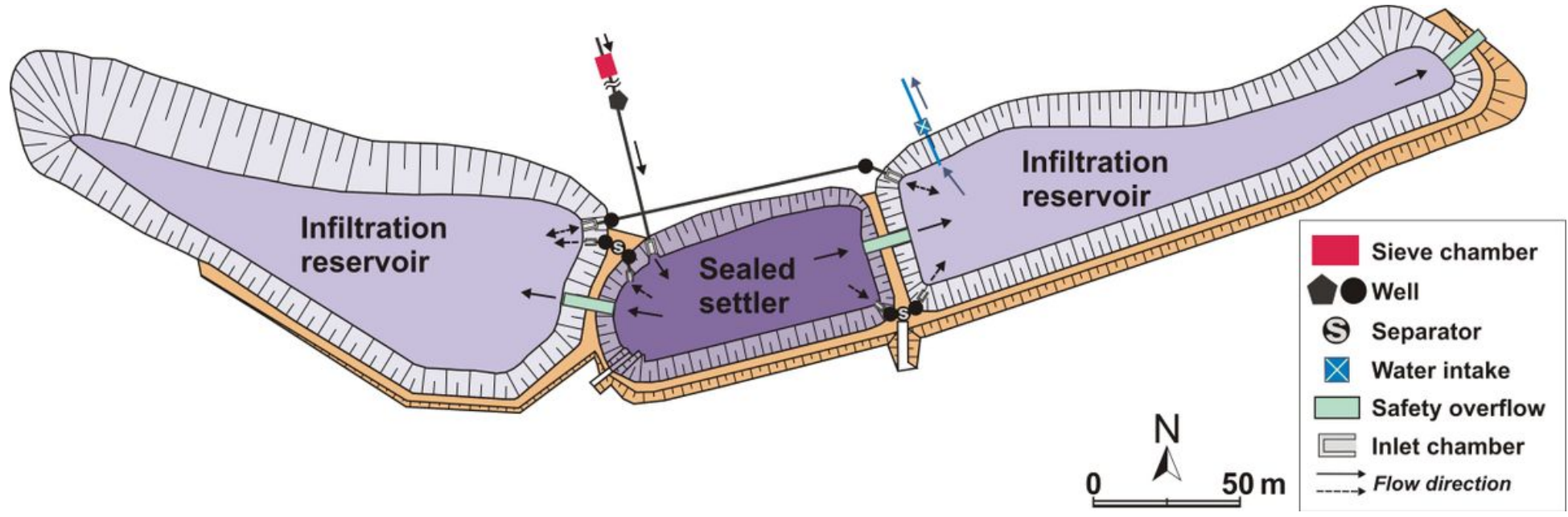

Figure 3

Rainwater harvesting and treatment system - variant 2 (2014-2020) 

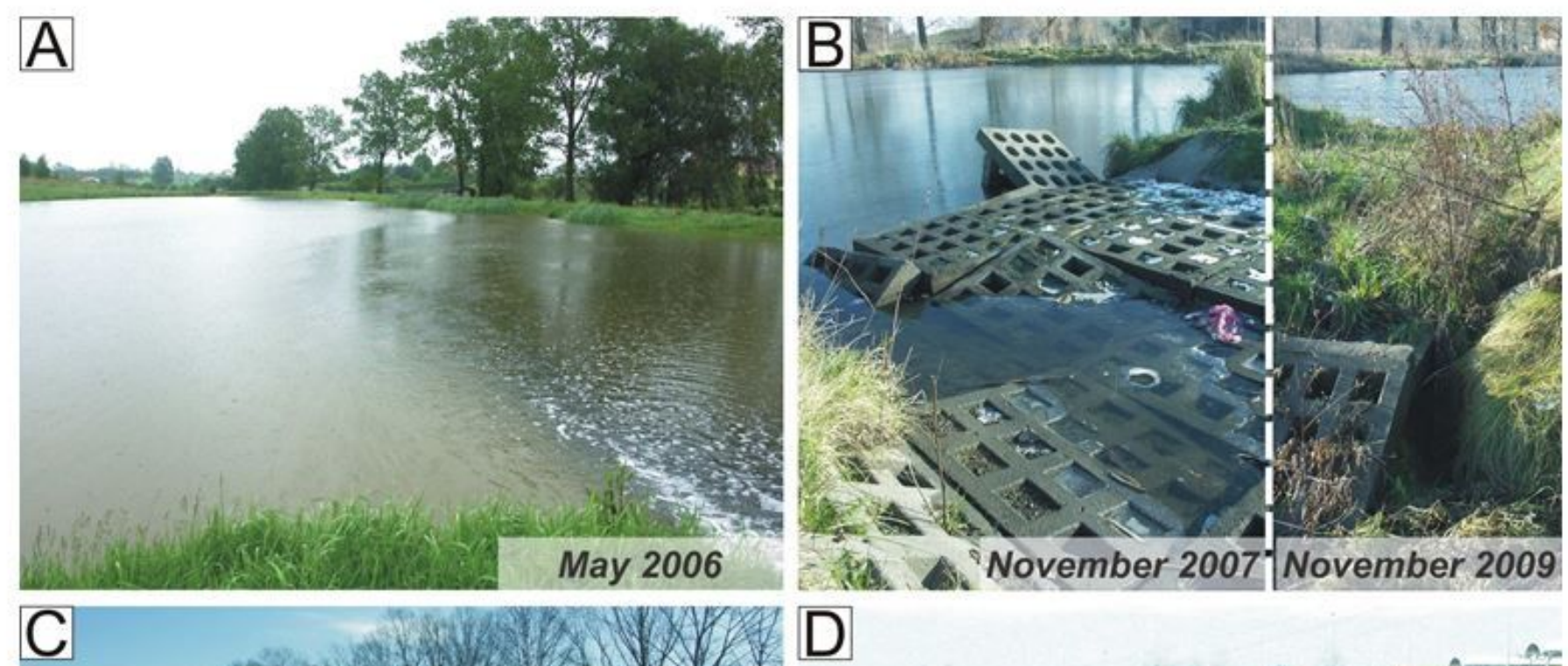

May 2006
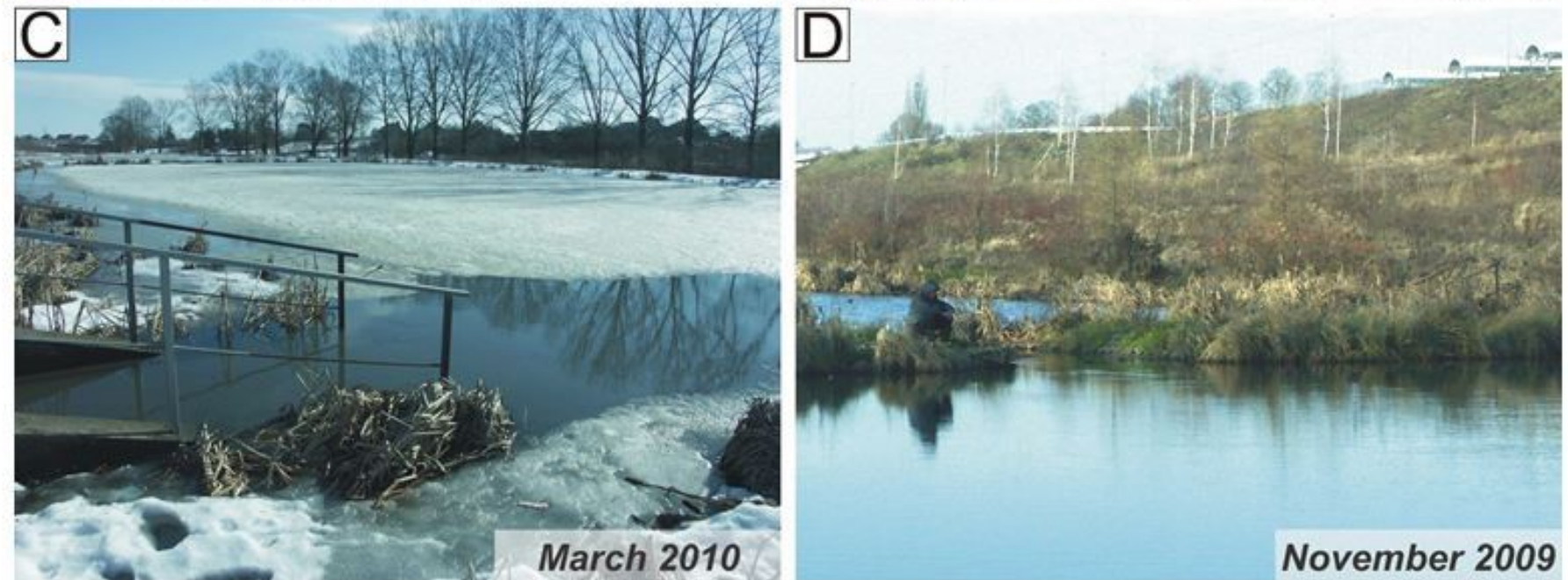

November 2009

\section{Figure 4}

Examples of operating problems in the RHTS - variant 1 (1999-2014): A) uncontrolled influx of the eroded loess material into the infiltration reservoir (increased turbidity near the left bank); B) damage of safety overflows due to erosion; C) extreme high level of filling of the reservoirs; D) illegal use of the rainwater reservoirs (angling) 

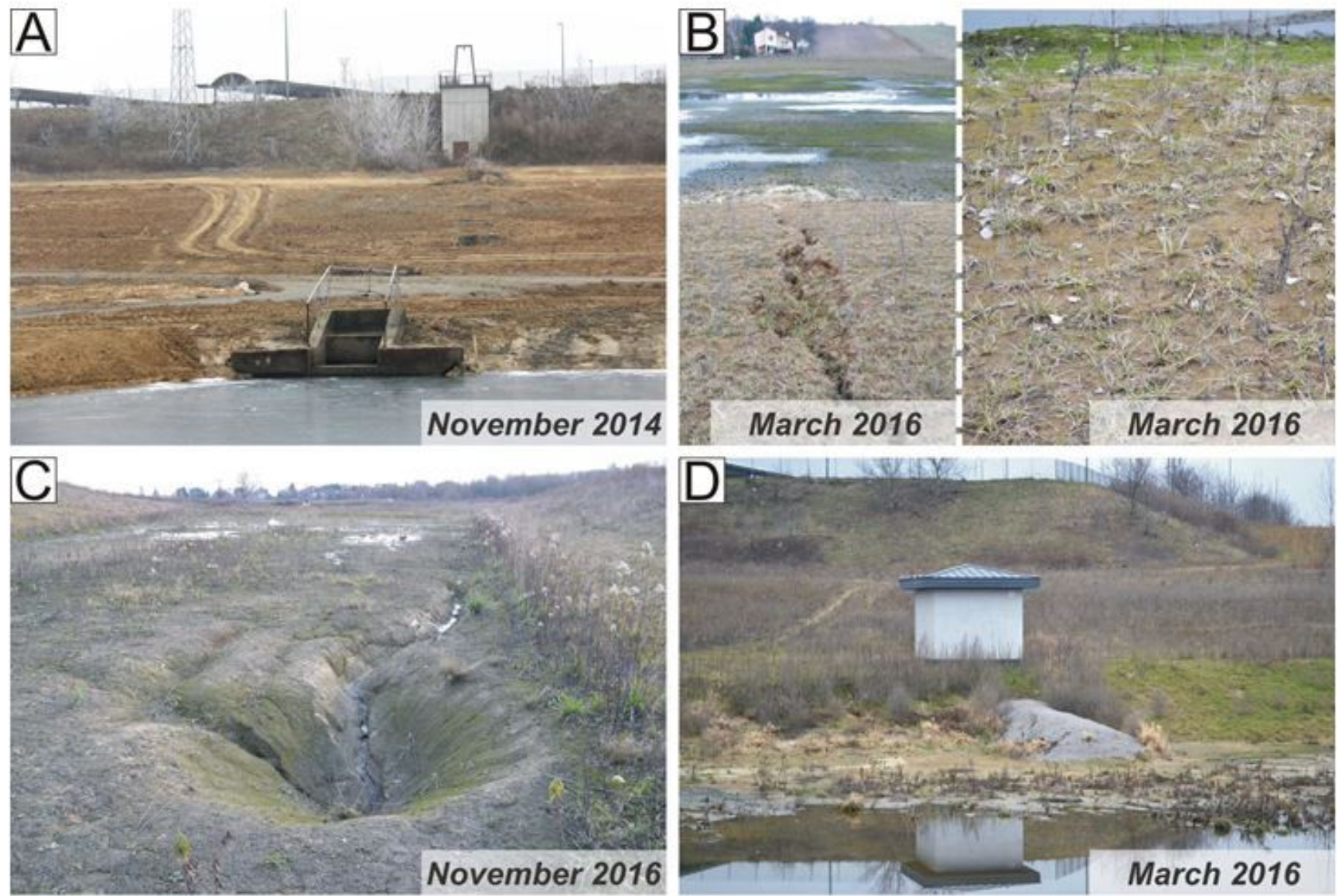

\section{Figure 5}

Examples of operating problems in the RHTS - variant 2 (2014-2020): A) the risk of influx of the products of erosion from the steep northern slope; B) rill and surface erosion on the escarpments of the reservoirs; C) piping in the bottom of the western infiltration reservoir; D) too high elevation of the intake of water after treatment. 